\title{
TO CONTINUE PROSPECTING: PERFORMANCE IMPLICATIONS OF COMBINATIVE CAPABILITIES AND EXPLORATIVE LEARNING
}

\author{
*Nor Liza ABDULLAH \\ **Abdul Latif SALLEH \\ *Prince Sultan University, Malaysia \\ **Universiti Kebangsaan, Kingdom of Saudi Arabia
}

\begin{abstract}
Knowledge is increasingly regarded as a primary strategic resource for firms and the processes involved in the knowledge domain becomes central to organizational success. This paper examines mediating effect of combinative capabilities in strategy-learning relationship. Using March's definition of explorative learning, this study attempts to identify the importance of combinative capabilities that are defined as system, socialization, and coordination capabilities to support explorative learning effort by firms. Responses from 208 manufacturing firms in Malaysia were analyzed using Structural Equation Modeling. Combinative capabilities were found to partially mediate the relationship between prospector strategic orientation and explorative learning. The findings also supported the hypothesis of negative relationship between system capabilities and explorative learning and positive relationship between coordination capabilities and explorative learning. However, the negative relationship postulated between socialization capabilities and explorative learning was not supported. The findings of this paper suggested that the choice of learning as incumbent to the strategy pursued by firms and alignment between learning and internal organizational mechanisms of firms is important to ensure proper implementation and significant results of the learning process.
\end{abstract}

Keywords: organizational learning, strategic management, resource-based, knowledge management

\section{INTRODUCTION}

The nature of competition nowadays that is driven by the heightened pace of change in communication technologies and advances in core technologies (Naman and Slevin, 1993) forces firms to become more prospector-oriented. Therefore, firms need to be more entrepreneurial, risk taker and strategically innovative in order to secure the benefit of being the first mover and market pioneer (Kerin, Varadarajan and Peterson, 1992; Robinson, Kalyanaram and Urban, 1994). O'Regan and Ghobadian (2006) found that high performing firms display higher proportion of prospector attributes and few other studies also suggested that greater prospector orientation tends to provide higher level of sustainability (Jennings and Zandbergen, 1995) with greater gains in market share, sales growth and new product sales in comparison with other strategic types (Matsuno and Mentzer, 2000).

The enduring nature of strategic orientation influences the development of internal policies and procedures applied in the organisations. Past studies have identified distinctive organisational behaviours in relation to different strategic orientation (e.g Manu and Sriram, 1996; Pleshko, 2007). The general conclusion from past studies that different approaches to learning may be required in different types of environments (e.g. Ghemawat and Costa, 1993; Burgelman, 2002), has some potentially interesting implications on strategy. As suggested by Fiol and Lyles (1985), strategy influences learning by setting the limits on the decision making process, and a context for perception and interpretation of the environment (Nieto and Quevedo, 2005). The objective of this paper is to examine the mediating role of combinative capabilities that will accelerate learning processes in prospector firms to performance. The study addresses the above issues by investigating the relationship between prospector strategic orientation, combinative capabilities and explorative learning. The study asserts that prospector firms should develop appropriate combinative capabilities in order to pursue explorative learning which is required in building innovativeness in the midst of a dynamic environment. 


\section{LITERATURE REVIEW}

March (1991) discusses two processes of learning; exploration for new knowledge and exploitation of existing knowledge. Exploration involves the use of new knowledge, skills and processes to increase variation and flexibility that are essential to effective adaptation (McGrath, 2001). Exploitation involves the use of existing knowledge, skills and processes to refine the existing system to improve efficiency (March, 1991). In a dynamic environment, exploration increases in importance because firms must be able to cope with increasing complexity and be ready for drastic change (Brown and Eisenhardt, 1998). According to Ghemawat and Costa (1993), dynamic environment requires firms to attain dynamic efficiency, which can be achieved through development of capabilities that help firms to explore and grab emerging opportunities. Evidently, changing and competitive landscape requires extensive learning through exploration to identify opportunities in the competitive climate and be flexible and creative in the pursuit and application of knowledge.

Emerging studies have acknowledged the relationship between learning and performance however less focus is given to the processes involved to support learning. In particular, very few studies have addressed the implications of combinative capabilities for the facilitation or prevention of organizational learning (Duncan and Weiss, 1979). Combinative capabilities are seen as the ability to recombine knowledge to generate new applications from existing knowledge and unexplored potential of technology (Kogut and Zander, 1992). According to Kogut and Zander (1992), combinative capabilities increase the ability to synthesise and apply current and acquired knowledge. Van den Bosch, Volberda and Boer (1999) have classified combinative capabilities into three categories of organisational mechanism; systems capabilities, coordination capabilities, and socialisation capabilities. System capabilities refer to direction, policies, procedures and manuals that are used to integrate explicit knowledge. It reflects the degree of formal system prevailed in the firm. On the other hand, coordination capabilities are essential in complex interaction processes that are required to enhance control and achieve performance. Coordination capabilities can be achieved through training and job rotation, participation and communication (Jansen, Van den Bosch and Volberda, 2006). Finally, socialisation capabilities refer to the ability to develop shared ideology that foster shared identity as well as collective interpretation of reality (Van den Bosch et. al, 1999). These capabilities stem from firm's culture in infusing beliefs and values over time that eventually produces distinct identity to the employees.

\section{Prospector Strategic Orientation and Explorative Learning}

Miles and Snow's (1978) prospector organisation is postulated to operate in a dynamic environment. Levinthal (1997) argues that in a dynamic situation (rugged landscape), "long jump" learning is needed which involves random exploration of more distant portions of the landscape (Levinthal and Warglien, 1999). Similarly, Burgelman (2002) proposes that in dynamic environment, firms require variation-increasing autonomous processes which involve exploiting initiatives that emerge through exploration outside of the scope of the current strategy, to enter into new product-market environments. By engaging into variation seeking initiatives, firms need to develop and retain new learning that will offer adaptiveness over a wider range of environmental variation and in a longer time horizon. It is essential for prospectors to develop new knowledge to capitalise on innovation and deter imitation. As proposed by Benner and Tushman (2003), in turbulent environments exploration was required to achieve radical, architectural and modular innovation. It is also suggested that in dynamic environment, entrepreneurial firms need to engage in proactive and extensive environmental scanning (Miles and Snow, 1978). According to Wang (2008, p.636), in order to pursue entrepreneurial efforts, "firms must be committed to learning, receptive to new information and new ways of doing things, and most importantly, engage in shared interpretation of information to achieve consensus on the meaning of the information". Therefore, based on the reasoning of environmental dynamism and innovation, this study posits that exploration is more closely related to prospectors. Therefore, this study postulates that there is a positive relationship between prospector strategic orientation and explorative learning.

\section{Hypothesis 1}

There is a positive relationship between prospector strategic orientation and explorative learning.

\section{Prospector Strategic Orientation and Combinative Capabilities}

Knowledge based theory sees firm as a body of knowledge residing in its structures of coordination, which in turn, defines the social context for cooperation, communication and learning (Lam, 2000). 
According to Ortenblad (2002) learning organisation prefer organic structure where information flows freely among people and across boundaries. According to Burns and Stalker (1961), organic structure which is characterised by loose structures and few rules is the most appropriate system in changing conditions. Flexibility is very important in learning organisation and it can be achieved by having decentralised structure that confers greater empowerment to workers (Senge, 1990). In relation to combinative capabilities, flexibility is characterised by low system capabilities. This is supported by Walker and Ruekert (1987) that suggested that prospectors' performance will be enhanced when there is flexibility in the implementation of decision-making and rules and policies. Formalization is suggested to drive out creativity (Lenz and Lyles, 1983) and has inherent ability to discourage the pursuit of opportunities (Fredrickson, 1986). Therefore, the study believes that firms with greater prospector strategic orientation will have lower system capabilities.

\section{Hypothesis 2}

Prospector strategic orientation is negatively related to system capabilities.

Since prospectors are continuously developing new products, they need to develop and integrate multiple technologies and this requires flexible structures to coordinate various functions involved (Laugen, Boer and Acur, 2006). Coordinated integration of the firm's resources is considered important in creating superior value and the synergistic effects of such coordination are obviously related to the orientations of the firm (Kohli and Jaworski, 1990; Narver and Slater, 1990; Gatignon and Xuereb, 1997). This is in line with Miles and Snow's (1978) proposal that prospectors tend to have complex coordination and communication mechanisms because their strengths rely on participative and decentralised decision making. Therefore, because of a higher level of conflict in prospectors, greater coordination capabilities are required to resolve and integrate processes (Ruekert and Walker, 1987). Furthermore, Walker and Ruekert (1987) propose that performance of prospectors depends on decentralised decision making procedures are supplanted by discretion and existence of informal coordination. According to information processing literature, decentralised structure which usually involves interdepartment task interdependence, not only increases the need for departmental information increasing power, but also need coordinative power (Siggelkow and Rivkin, 2006). Thus, it is justified to conclude that firms with greater prospector strategic orientation requires coordination capabilities to support their strategic objectives.

\section{Hypothesis 3}

Prospector strategic orientation is positively related to coordination capabilities.

Socialisation capabilities are found in firms with a strong identity and are manifested in a coherent set of beliefs, a high degree of shared values, a common language, and a strongly agreed-upon kind of appropriate behaviour. Although socialisation capabilities will eventually develop trust and translated into commitment, socialisation capabilities may inhibit the activities of prospectors. An increase in the socialisation rate is said to reduce experimentation which is essential in innovative orientation (Rodan, 2005). As socialisation capabilities lead to convergence in beliefs, it will restrict change which is crucial in dynamic environment. There is also broad agreement in the literature that dense shared understanding and beliefs may induce firms to be more risk averse (Lester and Canella, 2006) which will likely limit firm's ability to grow and to innovate (Cho and Pacik, 2005). Shared understanding and beliefs also influence firm's susceptibility to environmental change. Firms with "strongly held values' will try to maintain stability and avoid jolts (Lyles and Schwenk, 1992). Although some studies believe that shared vision and values increases commitment in organizational learning (Baker, Sinkula and Noordewier, 1997), however under different context, it may hinder the process of explorative learning.

\section{Hypothesis 4}

Prospector strategic orientation is negatively related to socialisation capabilities.

\section{Combinative Capabilities and Explorative Learning}

Exploration is more likely to flourish in a system that encourages improvisation and experimentation; where information flows are frequent and dense and roles and job are undefined (McGrath, 2001). This implies that flexibility in terms of goal-setting and delegation of supervision authority are desirable to stimulate exploration. When greater autonomy is given, employees have the freedom to be creative and to respond quickly to market opportunities (Birkinshaw, Nobel and Ridderstrale, 2002). 
The circumstances which allow greater individual discretion will also increase motivation and commitment. In another context, Zaltman (1979) argues that formalised structures that lead to codified knowledge can be rigid, making it difficult to acquire and utilise knowledge. Codification can lead to a general increase in organisational inertia (Zollo and Winter, 2001) and is more often will reduce the variability of performance rather than increasing it (Leonard-Barton, 1995; Kang, Morris and Snell, 2007). As argued by Fredrickson (1986), when systems are so formalised, they drive out creative and proactive behaviour. Therefore, the increase in flexibility can result in increased creation of knowledge (Lee and Choi, 2003) and this lead to the conclusion that explorative learning that is associated with dynamic environment and rapid changes in technology require less system capabilities.

\section{Hypothesis 5}

Explorative learning is negatively related to system capabilities.

Coordination capabilities become more critical as dynamic capabilities require decentralisation and knowledge must be integrated in order to achieve competitive advantage (Siggelkow and Rivkin, 2006). It is suggested that decentralisation is necessary to encourage exploration and experimentation with creative ideas among employees (Douglas and Judge, 2001). According to Daft and Huber (1987) learning is a function of information load facing the organisation. For firms that emphasise on experimenting, they have to deal with high and abstract information load. Therefore the structure should be disaggregated so that it can involved many boundary -spanning people and departments, and aggressive data acquisition approach can be undertaken. A greater variety of specialists provides a more diversified knowledge base and increases cross-fertilisation of ideas, both of which results in more innovation (Kimberly and Evanisko, 1981). Higher participation of cross-functional teams that bring together different sources of expertise will also lead to effective product development ideas (Imai, Ikujiro and Takeuchi, 1985; McNamara and Fuller, 1999). Explorative firms need flow of collaborative ideas across the organisations to encourage creative ideas (Amabile, Conti, Coon, Lazenby and Heron, 1996). Therefore, coordination capabilities are important to reduce cross functional conflict and promote commitment. The efficient combination of different functional insights will transform firm's competencies into superior performance (Gima, 2005) and thus the relationship between explorative learning and coordinative capabilities should be positive.

\section{Hypothesis 6}

Explorative learning is positively related to coordination capabilities.

According to Gargiulo and Benassi (2000), strong and dense interconnections may actually limit employees' opportunities to explore varied knowledge domains by locking them into narrow social circles. For instance, a case study done in Scandinavian software company (Holmqvist, 2004) found that inter-organisational exploration between the company and outsider generate successful product development, however collaboration with internal partners did not bring positive results. Studies by Rosenkopf and Nerkar (2001) suggest that when search is based on external boundary spanning, firms will likely to engage in well-regarded technology. However, if rely on internal expertise, they are consigned to their own firm's level of expertise. Accordingly, socialisation capabilities is said to create "mental prisons" (De Leeuw and Volberda, 1996) that inhibits people from identifying what is important as important. As socialisation capabilities tend to develop strong cultures, it increases resistance to change especially in absorbing outside sources of knowledge that contradicts the existing shared beliefs. This is supported by the observation by Cohen and Levinthal (1990) that even single shared language can posed barrier to tap diverse external sources of knowledge. Therefore, it is concluded that socialisation capabilities leads to greater efficiency potential but lack scope and flexibility of knowledge absorption. Based on above arguments, this study posits that socialisation capabilities will limit the ability of firms to engage in explorative learning.

\section{Hypothesis 7}

Explorative learning is negatively related to socialisation capabilities.

\section{Combinative Capabilities in Strategy-Learning Relationship}

According to Olson, Slater and Hult (2005), superior performance for the chosen strategic stance is contingent on how well policy decisions and practices (e.g structure and behaviour) are aligned with the requirements of the specific strategy. This is in line with Fredrikson (1986) that exerted that a balance view of strategy must acknowledge that strategic decision process and its outcomes can be facili- 
tated, constrained, or simply shaped by organisational mechanisms such as organisational structure, and they may have important deterministic effects on its own. Accordngly, firms may devise the best strategy, but without appropriate internal mechanisms in place, strategic implementation may fail and this will jeopardise the achievement of organisation's goals.

Studies suggest that organisational mechanisms facilitate learning and the conditions that can support firms to be more explorative in line with its strategic orientation. In order for learning to happen, appropriate conditions and managerial processes are required for effective learning to occur (Ulrich, Jick and Von Glinow, 1993). The importance of combinative capabilities in developing absorptive capacity (Cohen and Levinthal, 1990) explains the mediating effect of combinative capabilities on explorative learning. The importance of absorptive capacity is in line with findings in organisational learning research that conceded knowledge as a critical resource for firms to built competitive advantage (Quinn, 1992; Drucker, 1993). Combinative capabilities positively influence explorative learning through stimulating firms to "unlearn" old ways of doing things; or through enabling flexibility and facilitating firms to coordinate diverse requirements of skill and expertise. Moreover, integration mechanisms such as coordination and participation are suggested to play a role in affecting explorative learning (Keil, Zahra and Maula, 2004). The existence of direct relationship between strategic orientation and explorative learning, the study postulates that combinative capabilities partially mediate the relationship between strategic orientation and explorative learning.

\section{Hypothesis 8}

Combinative capabilities partially mediate the relationship between prospector strategic orientation and explorative learning.

\section{RESEARCH METHODOLOGY}

This study employed a quantitative approach using mail questionnaire design. Questionnaire was sent to managing directors and chief executive officers of medium and large manufacturing firms in Malaysia. A multiple-item method was used to construct the questionnaires. Structural Equation Modeling (SEM) was utilized to test the proposed mediation model besides determining the existence of significant relationships to justify the proposed hypotheses. The method proposed by Baron and Kenny (1986) was employed to establish full or partial mediation between the variables in the model. Finally, a structural model will be presented to depict the link among latent variables involved in the study. The goodness of fit analysis will determine significance of the model.

\section{Measures}

The measurements used in this study were adopted from studies in strategic management and organizational learning literature. Since the measurements were adopted from prior research, a pilot study was conducted for the purpose of external validation. Feedback from the exercise was then incorporated to improve the questionnaire.

Prospector strategic orientation. Based on the assumption that firms pursue different degrees of prospector strategic orientation, this study employed likert scale approach in assessing prospective strategy. Likert scale approach in determining strategic orientation has been widely used and accepted in strategy research and gaining popularity in studies on Miles and Snow typology (e.g. Gatignon and Xuereb, 1997; Aragon Correa, 1998; Parnell and Hershey, 2005; Andrews, Boyne and Walker, 2006). The likert scale measurements used in this study were developed based on the work of Conant, Mokwa and Varadarajan (1990) and Covin and Slevin (1989) on entrepreneurial (8 items), engineering (5 items), and administrative (5 items) dimensions. Response was measured using 6-Likert scale ranging from 1 = "strongly disagree" to $6=$ "strongly agree".

Combinative capabilities. This study defined combinative capabilities according to the definition prescribed by Van den Bosch, Volberda and de Boer (1999) that classified combinative capabilities into three categories; systems capabilities, coordination capabilities, and socialisation capabilities. Since scant attention has been given to this concept, a generally accepted measurement was still elusive. Jansen, Van den Bosch and Volberda (2005) proposed system capabilities to be measured by formalisation, coordination capabilities to be measured by participation (Ruekert and Walker, 1987), and socialisation capabilities to be measured by connectedness.

Explorative learning. Due to the absence of a generally accepted measure of exploration orientation, experimentation was integrated in this study as another dimension in explorative learning besides em- 
ploying information acquisition dimension based on the work of Sidhu, Volberda and Commandeur (2004). This attempt will enrich the scant literature on exploration orientation measurement and allow the development of a more comprehensive measurement of explorative learning. Works from Yeung, Ulrich, Nason and Von Glinow (1999) were compiled to measure experimentation and measurements used by Sidhu, Volberda and Commandeur (2004) were used to measure information acquisition.

Performance. This study adopted a 14-item measure based on perceptual measure or self -reported items. Financial performance measurements were adopted from Lee and Choi (2003), while innovative performance was measured following He and Wong (2004) by asking respondents to indicate how successful their organisation was in developing new products, opening new markets, and improving production processes.

\section{FINDINGS}

SEM with AMOS software was used to test the model. An examination of the data indicates support for normal distribution of the data. Table 1 shows the descriptive statistics (mean and standard deviation), reliabilities and standardised loadings of the variables examined in the present study. Out of 1340 questionnaire sent out, 208 responses were received and used, which was about $16 \%$ of the total sample. The response rate of this study compared well to response rates reported for similar surveys (e.g Sidhu, Commandeur and Volberda, 2007) and considered acceptable in this type of research (Davig, 1986).

\section{Respondents}

The distribution of companies participated in this survey was quite balance with electronics and metal companies constitutes more than $30 \%$ of the respondents. This was followed by the machinery $(11 \%)$, chemical (10\%) and wood-based companies $(9 \%)$. The percentage of distribution of the respondents was quite similar with the actual distribution of the number of companies in the FMM database. This concluded that the distribution of sample respondents can be assumed to be representative. In terms of years of operation, most of the respondents in this survey $(80 \%)$ have been in operation for more than 10 years in the industry. This signifies that those participated in this survey were established companies and the learning process should be more prevalent and therefore easy to be identified. The potential of non-response bias was assessed using Armstrong and Overton (1977) procedure. The Levene's test for the assumption of equality of variances indicated that all variables except coordination capabilities were not significant. This indicates that the variances of the two groups of respondents were generally equal.

\section{Statistical Analysis}

Exploratory and confirmatory factor analyses were utilised for all study variables. Generally, the KMO index for all of the variables was found to be greater than .80 that indicates meritorious presence of inter-correlations in the data matrix. As for convergent validity, all items that collectively represented all constructs were significantly loaded into their intended factors with standardised loadings of 4 and above. In addition to convergent validity, the average variance extracted (AVE) results ranged between 0.655 and 0.878 which exceeded the .50 recommended threshold indicating construct validity. Reliability analysis revealed that the values of Cronbach's Alpha coefficient were above .70, except for socialisation capabilities which was slightly above the minimally acceptable level of .50. Analysis on correlation indicated that there was no multicollinearity problem. 
TABLE 1.Results of Standardised Loadings and Reliability

\begin{tabular}{|c|c|c|c|c|c|}
\hline Constructs & Means & Std. Dev. & Std. loading & C.R & Cronbach \\
\hline $\begin{array}{l}\text { Prospector strategic orienta- } \\
\text { tion } \\
\text { Innovative } \\
\text { Product competitiveness } \\
\text { Aggressive } \\
\text { First Mover }\end{array}$ & $\begin{array}{l}3.411 \\
3.281 \\
3.855 \\
3.501\end{array}$ & $\begin{array}{l}1.035 \\
1.153 \\
0.956 \\
1.198\end{array}$ & $\begin{array}{l}0.717 \\
0.673 \\
0.837 \\
0.582\end{array}$ & $\begin{array}{c}10.336 \\
8.734 \\
10.336 \\
7.604\end{array}$ & 0.872 \\
\hline $\begin{array}{l}\text { Combinative Capabilities } \\
\text { System Capabilities } \\
\text { Coordination Capabilities } \\
\text { Socialisation Capabilities }\end{array}$ & $\begin{array}{l}3.487 \\
4.390 \\
4.919\end{array}$ & $\begin{array}{l}0.943 \\
0.751 \\
0.690\end{array}$ & $\begin{array}{l}0.577 \\
0.646 \\
0.796\end{array}$ & $\begin{array}{c}5.837 \\
7.436 \\
11.072\end{array}$ & $\begin{array}{l}0.776 \\
0.834 \\
0.595\end{array}$ \\
\hline $\begin{array}{l}\text { Explorative Learning } \\
\text { Experimentation } \\
\text { Acquisition }\end{array}$ & $\begin{array}{l}4.215 \\
3.535\end{array}$ & $\begin{array}{l}0.787 \\
0.883\end{array}$ & $\begin{array}{l}0.697 \\
0.697\end{array}$ & $\begin{array}{l}8.891 \\
8.891\end{array}$ & 0.814 \\
\hline $\begin{array}{l}\text { Performance } \\
\text { Financial } \\
\text { Product innovation } \\
\text { Process innovation }\end{array}$ & $\begin{array}{l}3.412 \\
3.444 \\
3.529\end{array}$ & $\begin{array}{l}0.752 \\
0.665 \\
0.707\end{array}$ & $\begin{array}{l}0.630 \\
0.681 \\
0.530\end{array}$ & $\begin{array}{l}5.392 \\
5.953 \\
5.392\end{array}$ & 0.848 \\
\hline
\end{tabular}

From the structural equation analysis, prospector strategic orientation has a significant positive effect (standardised coefficient $=0.556$ ) on explorative learning. This indicated that companies with greater prospective orientation have greater extent of explorative learning. Prospector strategic orientation was positively related to coordination (standardised coefficient $=0.411$ ) and socialisation capabilities (standardised coefficient $=0.339$ ), but negatively related to system capabilities (standardised coefficient $=-0.545$ ). In other words, companies with prospector strategic orientation will put in place greater organisational mechanisms to encourage coordination and socialisation capabilities but less for system capabilities. In terms of variance explained, prospector strategic orientation explained $52 \%$ of the total variance in combinative capabilities.

As for the direct effects of combinative capabilities on explorative learning, coordination capabilities has significant positive direct effect on explorative learning (standardised coefficient $=0.313$ ). On the other hand, system capabilities has significant negative direct effect on explorative learning (standardised coefficient $=-0.253$ ). This implies that explorative learning will be enhanced by greater coordination capabilities and with lower system capabilities. Prospector strategic orientation and combinative capabilities explained $86 \%$ of the total variance in explorative learning. Significant paths are also observed between explorative learning and performance (standardised coefficient $=0.57$ ).

For the purpose of mediation analysis, procedure suggested by Baron and Kenny (1986) and Kelloway (1995) was adopted. The result in Table 2 indicated a significant improvement of fit from the partially-mediated model to full-mediation model. There was also significant improvement between partially-mediated model and the non-mediated model. Since both comparisons showed significant improvement, an examination of goodness of fit of the nested model was required to ascertain the best model. Based on the result of goodness of fit, partial mediation best explained the mediation effect of system, coordination and socialisation capabilities in prospector strategic orientation - explorative learning relationship. 


\section{FIGURE 1. Structural model}

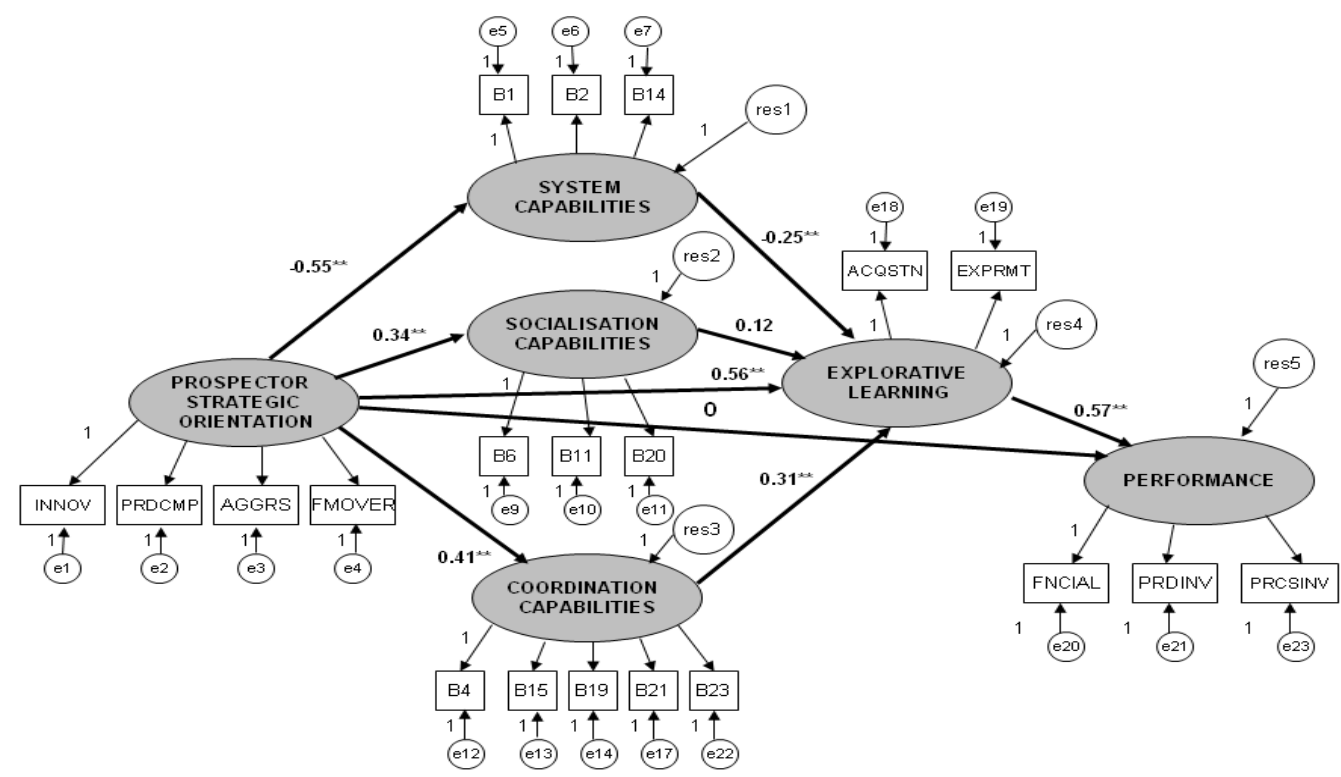

The structural model analysis suggested that the hypothesised model demonstrated an acceptable fitting to the sample data of $\chi^{2}=271.065, \mathrm{df}=162, \mathrm{p}<0.05$; $\mathrm{GFI}=0.893$; TLI $=0.908$; CFI $=0.916$; and RMSEA $=0.057$. A further check on the standardised residuals showed values below 2.58 (highest 2.455), indicating that there was no cross-loading or misspecification among the variables in the hypothesised model (Byrne, 2001). The values of MI for the structural paths posed nothing of concern. An examination of the structural model in figure 1 indicates significant paths between prospector strategic orientation and explorative learning (standardised coefficient $=0.56$ ), system capabilities (standardised coefficient $=-0.55$ ) and coordination capabilities (standardised coefficient $=0.41$ ). Significant paths are also observed between explorative learning and performance (standardised coefficient $=0.57$ ), system capabilities (standardised coefficient $=-0.25$ ) and coordination capabilities (standardised coefficient $=0.31$ ). These findings are summarised in table 3 .

\section{TABLE 3. Structural estimates for direct and mediated relationships}

\begin{tabular}{|c|c|c|}
\hline Hypotheses & $\beta$ & Findings \\
\hline $\begin{array}{l}\text { Direct relationship } \\
\text { Prospector strategic orientation } \rightarrow \text { Explorative learning } \\
\text { Prospector strategic orientation } \rightarrow \text { System capabilities } \\
\text { Prospector strategic orientation } \rightarrow \text { Coordination capabilities } \\
\text { Prospector strategic orientation } \rightarrow \text { Socialisation capabilities } \\
\text { System capabilities } \rightarrow \text { Explorative learning } \\
\text { Coordination capabilities } \rightarrow \text { Explorative learning } \\
\text { Socialisation capabilities } \rightarrow \text { Explorative learning } \\
\text { Explorative learning } \rightarrow \text { Performance } \\
\text { Mediated relationship } \\
\text { Prospector strategic orientation } \rightarrow \text { System Capabilities } \rightarrow \text { Explorative Learning } \\
\text { Prospector strategic orientation } \rightarrow \text { Coordination Capabilities } \rightarrow \text { Explorative Learning } \\
\text { Prospector strategic orientation } \rightarrow \text { Socialisation Capabilities } \rightarrow \text { Explorative Learning }\end{array}$ & $\begin{array}{l}0.556 * * \\
-0.545 * * \\
0.411 * * \\
0.339 * * \\
-0.253 * * \\
0.313 * * \\
0.12 \\
0.57 * *\end{array}$ & $\begin{array}{l}\text { Supported } \\
\text { Supported } \\
\text { Supported } \\
\text { Not supported } \\
\text { Supported } \\
\text { Supported } \\
\text { Not supported } \\
\text { Supported }\end{array}$ \\
\hline
\end{tabular}

** indicates the result is significant and supports the hypothesised relationship 


\section{DISCUSSION}

Studies have also argued that being prospectors, sustainable cost advantage can be achieved through learning or accumulation of experiences (Slater and Narver, 1993). This indicates the importance of learning is more prevalent in prospector firms. Furthermore, findings from Davig (1986) suggested that prospectors' success depends on the uniqueness or product differentiation which requires experimentation. Product research and development tend to be a distinctive competence of prospectors (Snow and Hrebeniak, 1980; McDaniel and Kolari, 1987; Morgan, Strong and McGuinness, 2003). Hall (1980) found that heavy investment in new product R\&D was a characteristic of many high performing firms in hostile environment.

Consistent with prior research on structural alignment, prospector strategic orientation works best with less system capabilities. As suggested by the literature, in innovative driven organisation, jobs are broadly defined and rarely rely on standard operating procedures. Instead employees are encouraged to find better ways of performing tasks. Besides low formalisation, coordination capabilities are also important in pursuing prospector strategic orientation. Study by Ruekert and Walker (1987) on interdivisional relationship based on Miles and Snow typology found that participatory mechanism was positively correlated with perceived effectiveness of the relationship between divisions, especially in prospector organisations.

An interesting discovery in this study is the positive relationship between prospective strategic orientation and socialisation capabilities. In the study of collaboration as knowledge management enablers (Lee and Choi, 2003), it was suggested that supportive and reflective communication helps to develop shared understanding about external and internal environment of the firm. This is supported by a study by Linnarson and Werr (2004) that found firms that work to achieve radical innovation promote open communication that will allow them to respond to competitive and market change. According to Jaworski and Kohli (1993), the greater individuals across departments are connected to each other, the more is the opportunity for them to exchange information and respond to it in a concerted fashion. Connectedness is suggested to play a facilitative role to reduce interdepartmental conflict and provide basis to align cross-functional activities that will lead to performance objectives.

Findings in this study have confirmed that effective learning requires alignment with organisational mechanisms in the firm (Liao, 2007). Exploration requires stimulation of knowledge creation through an injection of internal and external diversity. As found by McNamara and Fuller (1999), to move from exploitation to exploration requires the development of capabilities at two levels; operational level requires new capabilities in interdisciplinary research and upper management level requires capabilities in managing collaboration. In line with the findings, Jansen et. al (2005) found that coordination capabilities are positively related to potential absorptive capacity that is required in exploration of external knowledge. Benner and Tushman (2003) emphasised the importance of creating loosely coupled subunits to accommodate diversity and experimentation.

As for socialisation capabilities, it is interesting to note that the direction of the relationship is positive both in explorative learning and prospector strategic orientation. The centrality of information acquisition to exploration is framed as the importance of gaining fresh information to improve present and future returns in rational-choice (Radner and Rothschild, 1975) and bounded rationality models. What is being left out in March's model of exploration and exploitation is the role of interpersonal learning and tacit knowledge in knowledge creation (Miller, Zhao and Calantone, 2006). Local search (organisational level exploration) requires dense social interaction and proximity to generate internal knowledge creation and integration. The search process itself is highly tacit and therefore socialisation mechanism is important to ensure the effectiveness of the process. Moreover, in the process of knowledge transfer, "intimacy" and ease of communication are important especially in knowledge that has greater tacit components (Szulanski, 1996).

Since explorative learning was found to be important in developing innovative capabilities, there is an implication that explorative learning contributes to improvement in performance. This is further supported by findings from Sidhu et al. (2003) who showed that new product development success is more apparent in firms with greater prospector orientation. On the other hand, Jansen et al. (2006) found a positive relationship between exploration and financial performance when dynamism is high. This study specifically indicates that environmental dynamism determines the importance of pursuing exploration, thereby suggesting the relevance of exploration to prospector oriented firms. Since explorative learning involves the sharing of tacit knowledge, the positive relationship between sharing 
tacit knowledge and performance, as found by Keskin (2005) gives further support for the impact of explorative learning on performance.

The partial mediation hypothesis presented in this study was well supported in all types of combinative capabilities. This concludes that combinative capabilities play a role in supporting the extent of explorative learning in firms. In terms of coordination capabilities, the partial mediation result is in line with the findings by Gatignon and Xuereb (1997) that suggested interfunctional coordination enhanced the impact of strategic orientations in developing innovations. Furthermore, innovative firms were suggested to adopt cross-functional teams to facilitate communication (Kuratko, Ireland and Hornsby, 2001). Furthermore, in terms of socialisation capabilities, March's (1991) model of learning is portrayed to be mediated by organisational code which will influence the effectiveness of learning. Thus, the findings of this study establish the relationship between explorative learning and combinative capabilities. In line with prior research, this study supports the notion that formal structure and systems, sources of coordination and expertise and behaviour-framing attributes of the organisational context influence the number of attempts to transfer knowledge and the outcomes of those attempts (Ghoshal and Bartlett, 1994 and Szulanski, 1996).

\section{RESEARCH CONTRIBUTIONS}

This study contributes to the resource based view (RBV) that posited knowledge as the most important resource that need to be translated into internal competencies for innovation (Barney, 1991; Kogut and Zander, 1992). By addressing the needs of either allocating scarce resources to exploration as compared to exploitation, this study managed to present the contingent relationship between strategic orientation, organisational competencies (discussed as combinative capabilities) and explorative learning. This study also has advanced the organisational learning literature by investigating how companies with prospector strategic orientation and appropriate combinative capabilities can enhance explorative learning.

This study also contributes to the literature by being perhaps among the first to test empirically the relationship between combinative capabilities and explorative learning. The insignificant negative relationship between socialisation capabilities and explorative learning as postulated by March (1991) explained the absence of tacit knowledge in March's measures of exploration. This evidently has shown the importance of tacit knowledge in the discussion of explorative learning as highlighted in the study by Miller, Zhao and Calantone (2006). The findings of this study gives credence to the importance of tacit knowledge in innovation as proposed by Nonaka (1994) and future discussion of explorative learning should be extended to incorporate the role of tacit knowledge in encouraging experimentation and searching of information.

\section{LIMITATIONS}

Although the findings of this study provide insights into the dynamics of explorative learning, the results should be interpreted in the context of inherent limitations. Firstly, the data collection is confined to manufacturing sector in Malaysia. Although the study collected data from a variety of sectors in the manufacturing industry, and thereby achieved a greater source of variance, the generalisability of the findings to other industries is still limited. Furthermore, it is argued that the knowledge requirements in different industries may affect the extent of explorative learning (Garcia, Calantone and Levine, 2003). Therefore, it is suggested that future research can extend this study to sectors other than manufacturing to test whether the present measurement and substantive findings also hold in other contexts. Finally is the inherent limitation in using cross-sectional data. Although the conclusion of this study implied causal relationship, the causality cannot be clearly established in absence of longitudinal analysis (Sidhu et. al, 2007; Kickul and Gundry, 2002; Spector, 1981). It is suggested that future research could therefore verify causality by empirically using longitudinal data and lagged models. This would help to specifically measure the result of explorative learning that is contingent on strategy and combinative capabilities, rather than comparing differences associated with practices across firms (Benner and Tushman, 2003).

\section{SUGGESTIONS AND CONCLUSIONS}

Despite the above limitations, the findings of this study demonstrate that firms should develop their combinative capabilities to support explorative learning which is required in pursuing its strategic orientation. Future research on this issue should use longitudinal approach, by measuring explorative learning over time from multiple sources. As Lant and Mezias (1992) suggested from a simulation 
model of learning, it is important to consider the longitudinal dynamics in understanding learning in organisational convergence and reorientation.

In addition to the above potential of future studies, the notion that the knowledge base will eventually erode in the long run and the ability to exploit will deteriorate through time, has compelled researchers to investigate ways to rejuvenate learning from different perspectives. Future research should explore the issue of resource allocation, especially in respect of how to optimise resource distribution in order to achieve balance in terms of exploration and exploitation. There is ample evidence in the literature that firms are striving to find mechanisms that allow them to excel in both operational efficiency and innovation. However, the attempts are still limited in terms of empirical evidence and therefore, future studies should explore this notion since the findings will inevitably help firms in maintaining and improving competitiveness through time and that will ensure survival in the long run.

Another interesting venue for future research resides in the assumption contained within the Miles and Snow (1978) framework that all strategic types are equally viable across all environments (Zajac \& Shortell, 1989) and the opposing view that strategy is incumbent on the environment within which firms operate (DeSarbo et al., 2005). Although this study did not attempt to examine learning according to different types of strategic stance, it would be interesting to discover whether different types are equally likely to occur over time and place, and if this does not hold, whether there is a possibility that learning-related factors might contribute to the prevalence of different types of strategy. This proposition has some basis since findings from studies of top managers have suggested that their background, experience, and prior knowledge, all have some influence on their psychological and cognitive interpretations that shape strategic decisions. Therefore, future studies may examine the possibility of learning being an antecedent of strategy in an inter-related or cyclical form of relationship.

The findings and discussion have drawn attention to the need for further investigation to further understand the relationship between strategy and learning which is still elusive and lacking in empirical evidence. However, the findings of this study have managed to unravel new understanding related to the strategy-performance relationship that gives theoretical as well as practical implications to the existing body of knowledge. 


\section{REFERENCES}

Amabile, T.M; Conti, R; Coon, H; Lazenby, J and Heron, M. (1996). Assessing the work environment for creativity. Academy of Management. 39(5), pp. 1154-1184

Andrew, R., Boyne. G.A and Walker, R.M. (2006). Strategy content and organizational performance: An empirical analysis. Public Administration Review, pp. 52-63

Aragon-Correa, J. (1998). Research notes: Strategic proactivity and firm approach to the natural environment. Academy of Management Journal, 41(5), 556-567

Barney, J. (1991). Firm resources and sustained competitive advantage. Journal of Management. 17, pp. $99-120$

Baron, R.M. and Kenny, D.A. (1986). The moderator-mediator variable distinction in social psychological research: Conceptual, strategic, and statistical considerations. Journal Personality and Social Psychology. 15(6), pp. 1173-1182

Benner, M.J. and Tushman, M.L. (2003). Exploitation, exploration, and process management: The productivity dilemma revisited. Academy of Management Review. 28(2), pp. 238-256

Birkinshaw,J; R.Nobel and J.Ridderstrale. (2002).Knowledge as a contingency variable:Do the characteristics of knowledge predict organization structure?. Organization Science. 13(3), pp. 274-289

Brown, S.L. and Eisenhardt, K.M. (1998). Competing on the Edge-strategy as Structured Chaos. Harvard Business School Press: Boston

Burgelman, R.A. (2002). Strategy as vector and the inertia of co-evolutionary lock-in. Administrative Science Quarterly. 47, pp. 325-357

Burns and Stalker. (1961). The Management of Innovation. London: Tavistock, London, UK.

Cho, H.J. and Pacik, V. (2005). Relationship between innovativeness, quality, growth, profitability and market value. Strategic Management Journal. 26(6), pp. 555-575

Cohen, W.M. and Levinthal, D.A. (1990). Absorptive capacity: A new perspective on learning and innovation. Administrative Science Quarterly. 35, pp. 128-152

Conant J.S., Mokwa, M.P. and Vadarajan, P.R. (1990). Strategic types, distinctive marketing competencies and organizational performance. Strategic Management Journal. 11, pp. 365-383

Covin, J.G and Slevin, D.P. (1989). Strategic management of small firms in hostile and benign environments. Strategic Management Journal. 10(1), pp. 75-87

Daft, R.L., \& Huber, G. (1987). How organizations learn: A communication framework. Research in Sociology of Organizations, 5(2), pp. 1-36

Davig, W. (1986). Business strategies in smaller manufacturing firms. Journal of Small Business Management. 38- 46

De Leeuw, A.J.C. and Volberda, H.W. (1996). On the concept of flexibility: A dual control perspective. Omega. 2, pp. 121-139

Desarbo, W.S., Di Benedetto, C.A., Song, M., \& Sinha, I. (2005). Extending the Miles and Snow strategic framework: Strategic types, capabilities, environmental uncertainties, and firm performance. Strategic Management Journal, 26(1), pp. 47-74

Drucker, P. (1993). Post Capitalist Society. Butterworth-Heinemann : Oxford

Duncan, R and Weiss, A. (1979). Organizational learning : Implications for organizational design. Research in Organizational Behaviour. 1, pp. 75-123

Douglas T.J. and Judge, W.Q. (2001). Total quality management implementation and competitive advantage: The role of structural control and exploration. Academy of Management Journal. 44(1), pp. $158-169$

Fiol, C.M. and Lyles, M.A. (1985). Organizational learning. Academy of Management Review. 10, pp. 803-813

Frederickson, J.W. (1986). The strategic decision process and organizational structure. Academy of 
Management Review. 11(2), pp. 280-297

Garcia, R; Calantone, R and Levine,R. 2003. The role of knowledge in resource allocation to exploration versus exploitation in technologically oriented organizations. Decision Science. 34(2), pp. 323349

Gargiolo, M. and Benassi, M. (2000). Trapped in your own net? Network cohesion, structural holes and the adaptation of social capital. Organization Science. 11, pp.183-196

Gatignon, H. And Xuereb, J.M. (1997). Strategic orientation of the firm and new product performance. Journal of Marketing Research. 34, pp. 77- 90

Ghemawat, P. and J.R Costa. (1993). The organizational tension between static and dynamic efficiency. Strategic Management Journal. 14, pp. 59-73

Ghoshal, S., \& Bartlett, C.A. (1994). Linking organizational context and managerial action: The dimensions of quality of management. Strategic Management Journal, 15, pp. 27-43

Gima, K.A. (2005). Resolving the capability-rigidity paradox in new product innovation. Journal of Marketing. 69, pp.61-83

Hall, W.K (1980). Survival strategies in a hostile environment. Harvard Business Review. 58(5), pp. $75-85$

He, Z. H and Wong, P.K. (2004). Exploration vs. Exploitation : An empirical test of the ambidexterity hypothesis. Organization Science. 15(4), pp. 481-494

Holmqvist, M. (2004). Experiential learning processes of exploration and exploitation within and between organizations: An empirical study of product development. Organization Science, 15(1), pp. 70 -81 .

Imai, K., Ikujiro, N., Takeuchi, H. (1985), "Managing the new product development process: how Japanese companies learn and unlearn", in Hayes, R.H., Clark, K., Lorenz (Eds), The Uneasy Alliance: Managing the Productivty - Technology Dilemma, Harvard Business School Press, Boston, MA, pp. 337-375

Jansen, J.P., Van den Bosch, A.J. and Volberda, H.W. (2005). Managing potential and realized absorptive capacity: How do organizational antecedents matter? Academy of Management Journal. 48 (6), pp. 999-1015

Jansen, J.P., Van den Bosch, A.J. and Volberda, H.W. (2006). Exploratory innovation, exploitative innovation and performance: Effects of organizational antecedents and environmental moderators. Management Science. 52(11), pp. 1661-1674

Jennings, P.D., \& Zandbergen, P.A. (1995). Ecologically sustainable organizations: An institutional approach. Academy of Management Review, 20(4), pp. 1015-1052

Jaworski, B.J., \& Kohli, A.K. (1993). Market orientation: Antecedents and consequences. Journal of Marketing, 57, pp. 53-70

Kang, S.C., Morris, S.S. and Snell, S.A. (2007). Relational archetypes, organizational learning and value creation: Extending the human resource architecture.Academy of Management Review. 32(1), pp. 236-256

Keil, T., Zahra, S.A and Maula, M.V. (2004). Explorative and exploitative learning from corporate venture capital: A model of program level determinants. Academy of Management Best Conference Paper

Keskin, H. (2005). The relationship between explicit and tacit oriented KM strategy, and firm performance. The Journal of American Academy of Business, 7(1), pp. 169-175

Kickul, J and Gundry, L.K. (2002). Prospecting for strategic advantage: The proactive entrepreneurial personality and small firm innovation. Journal of Small Business Management. 40(2), pp. 85-97

Kimberly, J.R., \& Evanisko, M.J. (1981) Organizational innovation: The influence of individual, organizational, and contextual factors on hospital adoption of technological and administrative innovations. The Academy of Management Journal, 24(4), pp. 689-713 
Kogut, B. and Zander, U. (1992). Knowledge of the firm, combinative capabilities and the replication of technology. Organization Science. 3(3), pp. 383-397

Kogut, B and U. Zander. (1993). Knowledge of the firm and the evolutionary theory of the multinational corporation. Journal of International Business Studies, pp. 625-645

Kohli, A.K. and Jaworski, B.J. (1990). Market orientation: The construct, research proposition, and managerial implications. Journal of Marketing. 54(2), pp. 1-18

Kuratko, D.F., Ireland, R.D., Hornsby, J.S. (2001), "Improving firm performance through entrepreneurial actions: Acordia's corporate entrepreneurship strategy", Academy of Management Executive, 15(4), pp. 60-71

Lam, A. (2000). Tacit knowledge, organizational learning and societal institution: An integrated framework. Organization Studies. 21:3, pp.487-513

Lant, T.K. and Mezias, S.J. (1992). An organizational learning model of convergence and reorientation. Organization Science. 3(1), pp. 47-71

Laugen, B.T., Boer, H., \& Acur, N. (2006). The new product development improvement motives and practices of Miles and Snow's prospectors, analysers and defenders. New Product Development Improvement Motives and Practices, 15(1), pp. 85-95

Lee, H and Choi, B. (2003). Knowledge management enablers, process and organizational performance : An integrative view and empirical examination. Journal of Management Information System. 20(1), pp. 179-228

Lenz, R.T., \& Lyles, M.A. (1983). Crippling effects of "hyper-rational" planning. Faculty working paper no. 965. College of Commerce and Business Administration, University of Illinois at UrbanaChampaign

Leonard-Barton, D. (1995). Wellsprings of knowledge. Harvard Business School Press. Boston, MA

Lester, R.H., \& Canella, A.A. (2006). Interorganizational familiness: How family firms use interlocking directorates to build community-level social capital. Entrepreneurship Theory and Practice, 30(6), pp. $755-776$

Levinthal, D.A. (1997). Adaptation on rugged landscape. Management Science. 43, pp. 934-950

Levinthal, D.A., \& Warglien, M. (1999). Landscape Design: Designing for Local Action in Complex Worlds. Organization Science, 10(3), pp. 342-357

Liao, Y.S. (2007). The effects of knowledge management strategy and organization structure on innovation. International Journal of Management. 24(1), pp. 53-60

Linnarson, H and Werr, A. (2004). Overcoming the innovation-alliance paradox: A case study of an explorative alliance. European Journal of Innovation Management. 7(1), pp. 45-55

Lyles, M.A. and Schwenk, C.R. (1992). Top management, strategy and organizational knowledge structures. Journal of Management Studies. 29(2), pp. 155-174

March, J. (1991). Exploration and exploitation in organizational learning. Organization Science.2(1), pp. $71-87$

Manu, F.A. and Sriram, V. (1996). Innovation, marketing strategy, environment, and performance. Journal of Business Research. 35, pp. 79-91

Matzuno, K. and Mentzer, J.T. (2000). The effects of strategy type and market orientationperformance relationship. Journal of Marketing. 64, pp. 1-16

McDaniel, S.W. and Kolari, J.W. (1987). Marketing strategy implications of the Miles and Snow strategic typology. Journal of Marketing. 51, pp. 19-30

Kelloway, E.K. (1995). Structural equation modeling in perspective. Journal of Organizational Behavior. 16 , pp. $215-224$

McGrath, R.G. (2001). Exploratory learning, innovative capacity and managerial oversight. Academy of Management Journal. 44(1), pp. 118-131 
McNamara, P. and Fuller, C. (1999). Lessons from the Celltech case: Balancing knowledge exploration and exploitation in organizational renewal. British Journal of Management. 10, pp. 291307

Miles, R.E and Snow, C.C. (1978). Organizational strategy, structure and process. New York: McGraw Hill

Miller, K.D., Zhao, M. and Calantone, R.J. (2006). Adding interpersonal learning and tacit knowledge to March's exploration-exploitation model. Academy of Management Journal. 49(4), pp. 709-722

Morgan R.E., Strong, C.A. and McGuinness, T. (2003). Product-market positioning and prospector strategy: An analysis of strategic patterns from the resource-based perspective. European Journal of Marketing. 37(10), pp. 1409-1439

Naman, J.L and Slevin, D.P. (1993). Entrepreneurship and the concept of fit: A model and empirical tests. Strategic Management Journal. 14, pp. 137-153

Narver, J.C. and Slater, S.F. (1990). The effect of market orientation on business profitability. Journal of Marketing. 54(4), pp. 20-35

Nieto, M and Quevedo, P. (2005). Absorptive capacity, technological opportunity, knowledge spillovers, and innovative effort. Technovation. 25, pp. 1141-1157

Nonaka, I. (1994). A dynamic theory of organizational knowledge creation. Organization Science. 5 (1), pp. 14-37

Olsen, E.M., Slater, S.F. and Hult, G.T.M. (2005). The performance implications of fit among business strategy, marketing organization structure, and strategic behavior. Journal of Marketing. 69 (July), pp. 49-65

O'Regan, N. and Ghobadian, A. (2006). Perceptions of generic strategies of small and medium sized engineering and electronics manufacturers in the UK. Journal of Manufacturing Technology Management. 17(5), pp. 603-620

Ortenblad, A. (2002). A typology of the idea of learning organization. Management Learning. 33(2), pp. 213-230

Parnell, J.A. and Hershey, L. (2005). The strategy-performance relationship revisited: The blessing and curse of the combination strategy. International Journal of Commerce and Management. 15(1), pp. 17- 33

Pleshko. L.P. (2007). Strategic orientation, organizational structure and the associated effects on performance. Journal of Financial Services Marketing 12(1), pp. 53-64

Quinn, J.B. (1992). Intelligent enterprise: A knowledge and service based paradigm for industry. The Free Press: New York

Radner, R. and Rothschild, M. (1975). On the allocation effort. Journal of Economic Theory. 10, pp. 358-376

Robinson, W.T., Kalyanaram, G., \& Urban, G.L. (1994). First-mover advantages from pioneering new markets: A survey of empirical evidence. Review of Industrial Organization, 9, pp. 1-23

Rodan, S. (2005). Exploration and exploitation revisited: Extending March's model of mutual learning. Scandinavian Journal of Management. 21, pp. 407-428

Rosenkopf, L. and Nerkar, A. (2001). Beyond local search: Boundary spanning, exploration, and impact in the optical disk industry. Strategic Management Journal. 22(4), pp. 287- 306

Ruekert, R.W. and Walker, O.C. (1987). Interactions between marketing R\&D departments in implementing different business strategies. Strategic Management Journal. 8, pp. 233-248

Senge, P.M. (1990). The Fifth Discipline: The Art and Practice of the Learning Organization. Century Business: London

Sidhu, J.S; H.R Commandeur and H.W Volberda. (2003). Measuring exploration orientation and its impact on innovation. Academy of Management Best Conference Paper

Sidhu, J.S., Volberda, H.W and Commandeur, H.R. (2004). Exploring exploration orientation and its 
determinants: Some empirical evidence. Journal of Management Studies. 41(6), pp. 913-932

Sidhu, J.S., Commandeur, H.R. and Volberda, H.W. (2007). The multifaceted nature of exploration and exploitation: Value of supply, demand and spatial search for innovation. Organization Science. 18 (1), pp. 20-38

Siggelkow, N. and Rivkin, J.W. (2006). When exploration backfires: Unintended consequences of multi-level organizational search. Proceedings from Academy of Management. New Orleans.

Slater, S.F. and Narver, J.C. (1993). Product market strategy and performance: An analysis of the Miles and Snow strategy types. European Journal of Marketing. 27(10), pp. 33-51

Snow, C.C. and Hrebiniak, L.G. (1980). Strategy, distinctive competence and organizational performance. Administrative Science Quarterly. 25, pp. 317-336

Szulanski, G. (1996). Exploring internal stickiness: Impediments to the transfer of best practice within the firm. Strategic Management Journal. 17(Winter), pp. 27-42

Ulrich, D., Jick, T. and Von Glinow, M. (1993). High impact learning: Building and diffusing learning capability. Organizational Dynamics. Autumn, pp. 52-66

Van den Bosch, F.A.J., Volberda, H.W. and de Boer, M. (1999). Co-evolution of firm absorptive capacity and knowledge environment: Organizational forms and combinative capabilities. Organization Science. 10, pp. 551-568

Walker, O.C. and Ruekert, R.W. (1987) Marketing's role in the implementation of business strategies: A critical review and conceptual framework, Journal of Marketing 51(3), pp. 15-33

Wang, C.L. (2008). Entrepreneurial orientation, learning orientation and firm performance. Entrepreneurship Theory and Practice, pp. 635-657

Yeung, A., Ulrich, D., Nason, S. and Von Glinow, M. (1999) Organizational learning capability. New York: Oxford University Press

Zaltman, G. (1979). Knowledge utilization as planned social change. Science Communication, 1(1), pp. $82-105$

Zollo, M and S.G Winter. (2002). Deliberate learning and the evolution of dynamic capabilities. Organization Science. 13(3), pp. 339-351 